\title{
Clonality of HTLV-2 in natural infection
}

\author{
Anat Melamed ${ }^{1 *}$, Aviva D Witkover ${ }^{1}$, Rachael Brown ${ }^{1}$, Kristin Ladell $^{2}$, Niall Gormley ${ }^{3}$, Edward L Murphy ${ }^{4}$, \\ Graham P Taylor ${ }^{5}$, David A Price ${ }^{2}$, Charles RM Bangham ${ }^{1}$ \\ From 16th International Conference on Human Retroviruses: HTLV and Related Viruses \\ Montreal, Canada. 26-30 June 2013
}

We recently developed a high-throughput sequencing method for analysis and quantification of HTLV-1 integration sites in the host genome (Gillet et al, 2011, Blood). Using this method we investigated the effect of the genomic environment on integration targeting, clonal expansion and spontaneous HTLV-1 proviral expression (Gillet et al, 2011, Blood, Melamed et al, 2013, PLoS Pathogens). HTLV-2 preferentially infects CD8+ T cells, with a minority of the proviral load in CD4+ $\mathrm{T}$ cells. Here we describe the use of our high-throughput technique to investigate the distribution of HTLV-2 proviral integration sites in the host genome, in peripheral blood mononuclear cell (PBMC) DNA of HTLV-2 infected individuals $(\mathrm{n}=28)$. We also mapped and quantified proviral integration sites separately in flow-sorted CD4 $+\mathrm{CD} 8$ - and CD4-CD8+ populations. We quantified the clone frequency distribution and clonal survival over time in 10 individuals, using samples from 2 time points separated by a median of 10 years. The results show that the clone frequency distribution of HTLV-2 in PBMCs is distinct from that of HTLV-1 and resembles that of HTLV1-infected CD8 $+\mathrm{T}$ cells. These results suggest that in both HTLV-1 and HTLV-2 infections, there is a greater degree of selective oligoclonal clonal expansion in infected CD8+ T cells than in CD4+ T cells. We are now investigating the selection forces that underlie this dichotomy between $\mathrm{T}$ cell lineages.

\section{Authors' details}

'Section of Immunology, Imperial College London, Wright-Fleming Institute, Norfolk Place, London, UK. ${ }^{2}$ Institute of Infection and Immunity, Cardiff University School of Medicine, Cardiff, Wales, UK. ${ }^{3}$ lllumina, Chesterford Research Park, Essex, Little Chesterford, UK. ${ }^{4}$ University of California San Francisco, California, USA. ${ }^{5}$ Section of Infectious Diseases, Imperial College London, Wright-Fleming Institute, Norfolk Place, London, UK.

'Section of Immunology, Imperial College London, Wright-Fleming Institute, Norfolk Place, London, UK

Full list of author information is available at the end of the article
Published: 7 January 2014

doi:10.1186/1742-4690-11-S1-P138

Cite this article as: Melamed et al: Clonality of HTLV-2 in natural infection. Retrovirology 2014 11(Suppl 1):P138.
Submit your next manuscript to BioMed Central and take full advantage of:

- Convenient online submission

- Thorough peer review

- No space constraints or color figure charges

- Immediate publication on acceptance

- Inclusion in PubMed, CAS, Scopus and Google Scholar

- Research which is freely available for redistribution

Submit your manuscript at www.biomedcentral.com/submit

\section{() Biomed Central}

C Biomed Central

(c) 2014 Melamed et al; licensee BioMed Central Ltd. This is an Open Access article distributed under the terms of the Creative Commons Attribution License (http://creativecommons.org/licenses/by/2.0), which permits unrestricted use, distribution, and reproduction in any medium, provided the original work is properly cited. The Creative Commons Public Domain Dedication waiver (http://creativecommons.org/publicdomain/zero/1.0/) applies to the data made available in this article, unless otherwise stated. 